Never Remember: Fake News Turning Points and Vernacular Critiques of Bad Faith Communication

Author(s): Diane E. Goldstein

Source: The Journal of American Folklore, Vol. 131, No. 522 (Fall 2018), pp. 471-481

Published by: University of Illinois Press on behalf of American Folklore Society

Stable URL: https://www.jstor.org/stable/10.5406/jamerfolk.131.522.0471

JSTOR is a not-for-profit service that helps scholars, researchers, and students discover, use, and build upon a wide range of content in a trusted digital archive. We use information technology and tools to increase productivity and facilitate new forms of scholarship. For more information about JSTOR, please contact support@jstor.org.

Your use of the JSTOR archive indicates your acceptance of the Terms \& Conditions of Use, available at https://about.jstor.org/terms 


\title{
Never Remember: Fake News Turning Points and Vernacular Critiques of Bad Faith Communication
}

\begin{abstract}
The February 2, 2017, false assertion by one of American President Donald Trump's advisors of a terrorist tragedy in Bowling Green, Kentucky, has been characterized as a moment of significance that constituted a break in the "fake news clouds." This article uses the vernacular response to the "Bowling Green Massacre" to understand the quick and decisive identification of bad faith communication and the strategic nature of resistance to hegemonic control over "fact" and "reality" in the wake of the Trump presidency. I explore the role of intertextuality, localization, and incongruity in the vernacular response to both a massacre that never happened and the overall phenomenon of fake news.
\end{abstract}

\section{Keywords}

AFS ETHNOGRAPHIC THESAURUS: Popular culture, propaganda, social media, digital media, mass media, contemporary legends

Everyday forms of resistance make no headlines.

- Scott (1985:xvi)

ON THE MORNING OF FEBRUARY 3, 2017, I texted Ann Ferrell in Bowling Green, Kentucky, to say: "So sorry about the Bowling Green Massacre. Kellyanne Conway is very concerned about it." Ann wrote back: "Thanks. It was such a scary time. I am so glad she's bringing attention to it." A little while later, Ann sent another text: "You can support us by donating to this fund." The page she sent said: "The Bowling Green Massacre Victims Fund-Join us in helping those in this time of need." ${ }^{1}$ When you clicked on the "donate now" button, it took you to the American Civil Liberties Union (ACLU) website. ${ }^{2}$

The texts between Ann and me followed news from the previous night. On February 2, 2017, Trump advisor Kellyanne Conway, in an interview with Chris Matthews, complained about the lack of media coverage of the "Bowling Green Massacre," a terrorist tragedy that she discussed as evidence of the need for a travel and immigration

DIANE E. GOLDSTEIN is Professor, Department of Folklore and Ethnomusicology, Indiana University 
ban from seven Muslim-majority countries (Beauchamp 2017). ${ }^{3}$ The Bowling Green, Kentucky, attack never happened, but the "massacre" quickly became both a joke and a spectacular symbol of the use by the Trump administration of untrue assertions to rally support for its agenda while at the same time denigrating as "dishonest" all other media reports. ${ }^{4}$ Referred to by Jim Rutenberg of the New York Times as a "turning point for fake news" (2017), the Bowling Green Massacre story was quickly and unquestioningly identified by the grass roots as false.

The day after the interview, Conway indicated that she misspoke and had been referring to the 2011 arrest of two Iraqi refugees in Bowling Green on charges of attempting to provide material support to terrorists (Coscarelli 2017). Conway, however, had said exactly the same thing using exactly the same phrasing twice before, on January 29-first to Cosmopolitan ${ }^{5}$ and a second time to TMZ $^{6}$ (D. Smith 2017).

As Ann and I were texting, the grassroots response to Conway was exploding in Bowling Green and around the United States, even internationally (see Evans 2018 for further discussion of the Bowling Green response). A vigil for the non-massacre non-victims happened so fast in Bowling Green and in New York City that several friends indicated that it was over before they heard about the event. The vigils included signs marked "RIP truth," "never remember," "we are all Bowling Green," and numerous other slogans.

Within days, buttons and T-shirts were manufactured, restaurants renamed food dedicated to the massacre, businesses held massacre sales, endless tweets and memes parodied the events, songs and poems were written, and videos were made.

Rutenberg argued that the Bowling Green Massacre "may go down in the record of the Trump presidency as the first break in the 'fake news' clouds that have cast such gloom over our fair and once (relatively) true republic" (2017). He noted, "The same internet that enabled false stories to run unchecked through news feeds during the

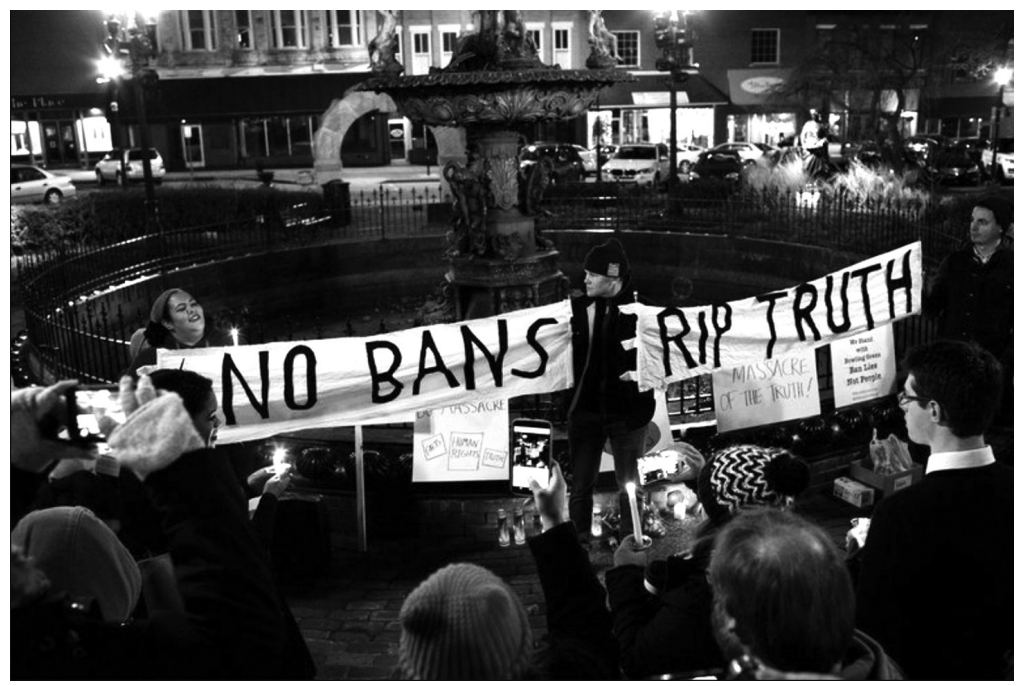

Figure 1. Bowling Green Massacre Vigil, Bowling Green, Kentucky. Erika Brady Bowling Green Massacre Collection (personal communication, October 12, 2017). 

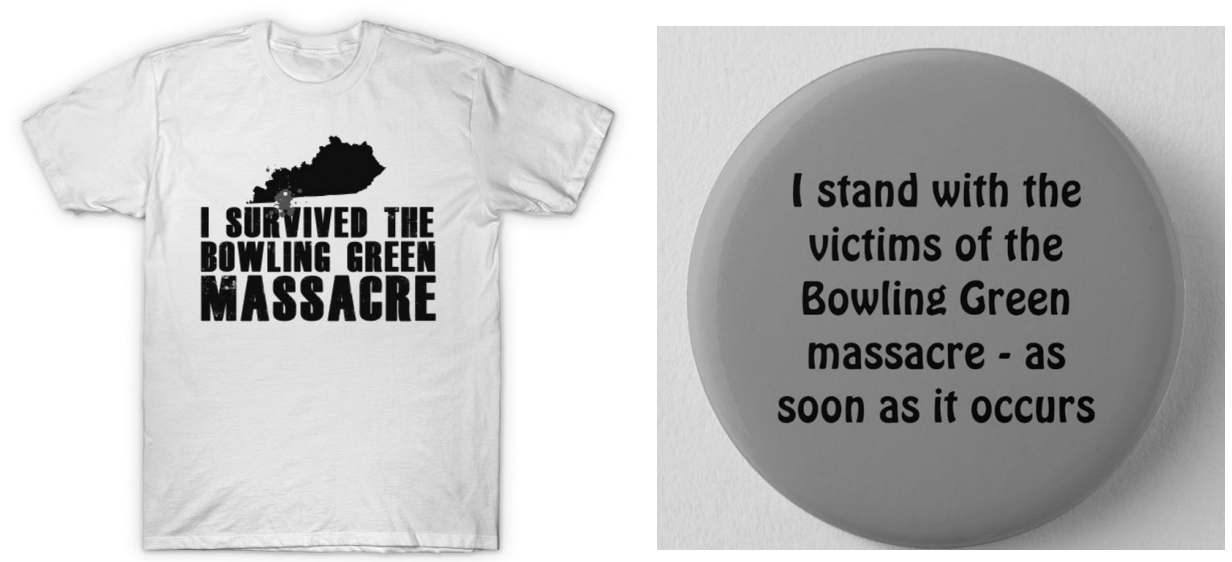

Figures 2 and 3. "I survived the Bowling Green Massacre" T-shirt and button. https://www .teepublic.com/t-shirt/1176882-i-survived-the-bowling-green-massacre; https://www.zazzle .com/bowling+green+massacre+gifts (accessed October 9, 2017.)

election year dispatched new white blood cells that attacked Ms. Conway's 'alternative facts' with 'true facts' (a redundant term that I guess we're stuck with for now)" (2017). The news media's response to Conway was joined by memes as well as Facebook and Twitter parodies, and, as Rutenberg noted, there was an organic correction movement led by ordinary users who were, in his terms, "crowdsourcing reality." Rutenberg argued, "In the end, social media and journalistic scrutiny aligned with comedy to right a wrong pretty definitively. That it happened so organically showed that false 'facts' might not always be the stubborn things so many people fear they are becoming" (2017).

In the months since Rutenberg's article, it has certainly been the case that false facts have been every bit as stubborn as we thought they were, but the wave of vernacular fight-back provides a sense of hope. The memes, fake vigils, T-shirts, renamed pizzas, and other commodities dedicated to the Bowling Green Massacre not only highlighted a quick and decisive vernacular condemnation of fake news production, but also identified the tools found within a vernacular arsenal of public critique. The Bowling Green Massacre response created a proactive strategic discursive model for identifying White House tactics, for replying to such tactics, and for assessing future communication. It created a template for seeing, identifying, and countering fake news yet to come, by ascertaining and parodying the discursive style of White House bad faith communication. A few observations might suffice to lay bare the work of that vernacular response.

\section{Intertextuality}

The parodied massacres, grave markers, historic plaques, and vigils turn the rhetoric to a massacre of truth, fact, and human rights, immediately highlighting the significance of the moment as an example of bad faith communication.

Through references to other Trump administration false or foolish statements such as those concerning Frederick Douglass, the size of crowds, and mention of Swedish 
survivors, the memes flagged intertextually an association with falsity and stupidity, borrowing prior texts as a discursive strategy to demonstrate the larger culture of ignorance, dishonesty, and false truth coming from the White House.

During the opening of Black History Month, on February 1, 2017, President Trump referred to former slave and abolitionist Frederick Douglass by saying that "Frederick Douglass is an example of somebody who's done an amazing job and is getting recognized more and more, I notice" (see Wootson 2017), suggesting that he had no idea who Frederick Douglass was or that he was long dead. Frederick Douglass memes and tweets were an intertextual favorite after Conway's Bowling Green comments, with one meme noting that "the Bowling Green Massacre was an American tragedy. May our nation never experience something like that again." This statement was signed "Frederick Douglass 2017."7 A tweet noted that "Frederick Douglass did great things after the Bowling Green Massacre. Tremendous things. Almost like it never happened." Another tweet said, "God I hope someone tells Trump that Frederick Douglass died in the Bowling Green Massacre" (Parthasarathy 2017).

Allusions to crowd size refer to Press Secretary Sean Spicer's first press briefing, in which he scolded reporters for suggesting that the turnout for Trump's big day was smaller than the turnout for President Obama's inauguration. President Trump claimed the media had misrepresented the number of people attending his inauguration, asserting in a speech at CIA headquarters that "one of the networks" had shown "an empty field," while he saw a crowd that "looked like a million-and-a-half people" and "went all the way back to the Washington Monument" (quoted in Robertson and Farley 2017). Photos of the crowd, including one taken at 12:01 p.m. from the top of the Washington Monument, clearly show that the crowd witnessing Trump's inauguration didn't extend all the way to the Washington Monument. Later that day, Spicer read a prepared statement criticizing the media for "dishonesty" and asserting that the January inauguration was the "largest audience to ever witness an inauguration, period, both in-person and around the globe" (quoted in Robertson and Farley 2017). To support his claim, Spicer said the photos were taken in a way that minimized the crowd, and previous inaugurations didn't employ white grass covering, which made

Figure 4. Historic marker. Erika Brady Bowling Green Massacre Collection (personal communication, October 12, 2017).

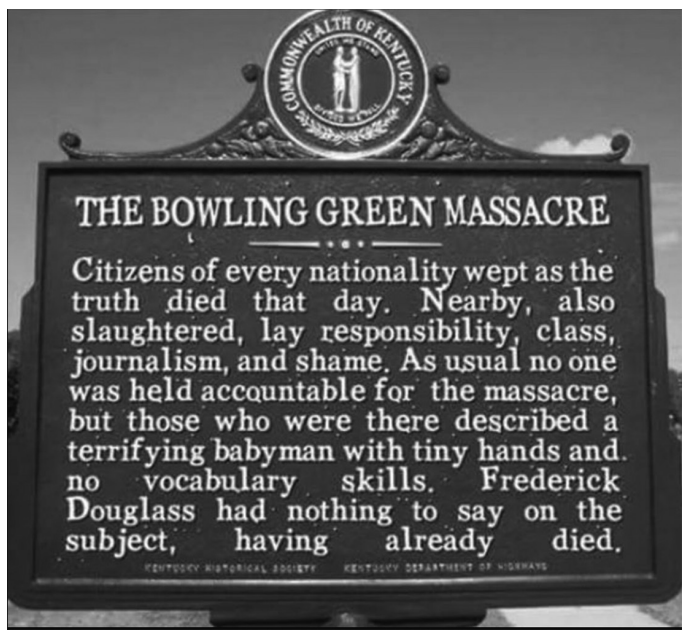

This content downloaded from 


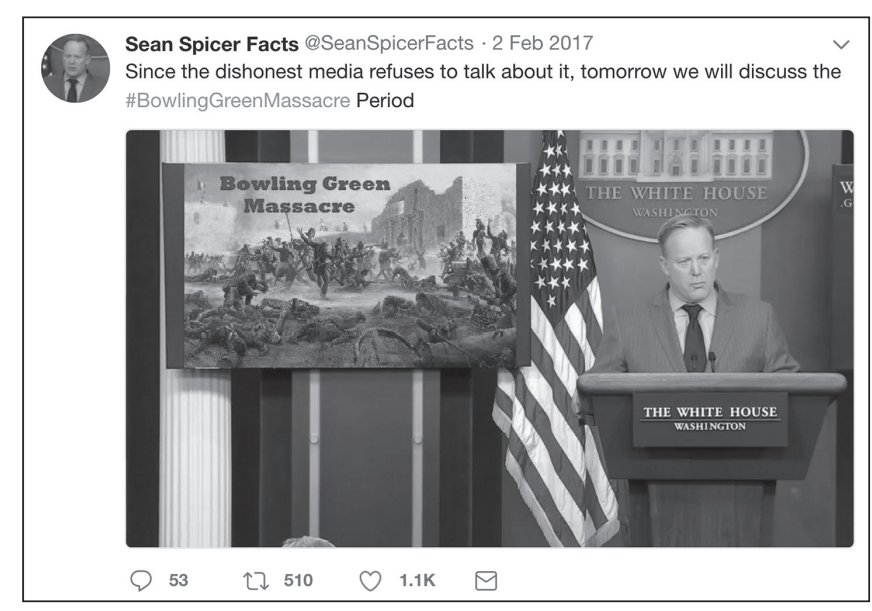

Figure 5. White House Press Secretary Sean Spicer depicted in a parody of an earlier press briefing on inaugural crowd size. Erika Brady Bowling Green Massacre Collection (personal communication, October 12, 2017).

the crowd look smaller (quoted in Robertson and Farley 2017). Chuck Todd, host of NBC's Meet the Press, asked White House counselor Kellyanne Conway "why the president asked the White House press secretary to come out in front of the podium for the first time and utter a falsehood." Conway responded, "Don't be so overly dramatic about it, Chuck. What-you're saying, it's a falsehood. And ... Sean Spicer, our press secretary, gave alternative facts to that." As Conway signaled the White House approach to truth, Todd responded to Conway, "Alternative facts are not facts. They are falsehoods" (NBC News 2017). While Conway might have referred to alternative perspectives or alternative data sets, she instead launched the approach to truth later seen by mainstream media and the public as a hallmark of the Trump administration.

Tweets and memes also targeted President Trump's February comments on Sweden, with several suggesting that "Sweden stood with Bowling Green, now we will stand with Sweden" (Rubin 2017). Similar to Conway's comments about the Bowling Green Massacre, at a rally in Melbourne, Florida, on February 18, 2017, President Trump defended his proposed travel ban by saying: "When you look at what's happening in Germany, when you look at what's happening last night in Sweden-Sweden! Who would believe this? Sweden! They took in large numbers; they're having problems like they never thought possible" (Rubin 2017). The reference to Sweden was widely understood, in the context of commenting on Germany, to be a suggestion that a terror attack had occurred. Carl Bildt, the former Swedish prime minister, questioned the president's statement on Twitter. He wrote, "Sweden? Terror attack? What has he been smoking?" (Rubin 2017).

The false reference understood to be suggesting a terror attack in Sweden was inspired by a segment on Tucker Carlson's show on Fox TV, when anti-immigration journalist Ami Horowitz claimed the Swedish government was covering up rape and other crimes in order to protect "vulnerable" migrants (O. Smith 2017). After 
American journalists and commentators responded to the falsity of the claim, Trump doubled down, tweeting, "Give the public a break-The FAKE NEWS media is trying to say that large scale immigration in Sweden is working out just beautifully. NOT!" (Rubin 2017). The Sweden comments came to symbolize the lengths the White House would go to cover up for the president's gaffes of fact, his inability to distinguish fact from fiction, and his belief in right-wing conspiracy theories (Rubin 2017).

Each of these intertextual references is representative of important moments in the public's gradual understanding of the White House approach to fact, fiction, and history. Like the old story about folklorists calling out motif numbers and laughing, the references to Frederick Douglass, crowd size, and Sweden provide kernel narratives (Kalčik 1975) that encapsulate important moments in public comprehension of the White House's assault on truth. As such, the intertextual response does not only respond to past untruths, but points out the discursive strategies that can be expected from the White House in the future. By incorporating concepts and ideological content derivative of those authoritative discourses, the memes and tweets create a critique that reaches both forward and back, identifying several moments of bad faith communication at one time while simultaneously creating a vernacular template for assessing future communication.

\section{The Power of the Local}

Many of the vernacular responses to the Bowling Green Massacre referenced the local, mixing symbols of Bowling Green, the South, or Kentucky with references to Conway, the White House, or the massacre itself. Historic markers displaying the Commonwealth of Kentucky signage refer to a list of names of victims of the massacre but then are left blank where names would be entered. The popularity of this image was evidenced by immediate variation in transmission and its massive re-posting.

Also marking the local were references to Bowling Green football, including images of the Hilltoppers football team with messages of grief or memes that play on Big Red, the team's mascot. Comments about previous Bowling Green (football) massacres were particularly common.

Figure 6. Parody of a Commonwealth of Kentucky historic marker but with blanks where victims would normally be listed.

Erika Brady Bowling Green Massacre

Collection (personal communication,

October 12, 2017).

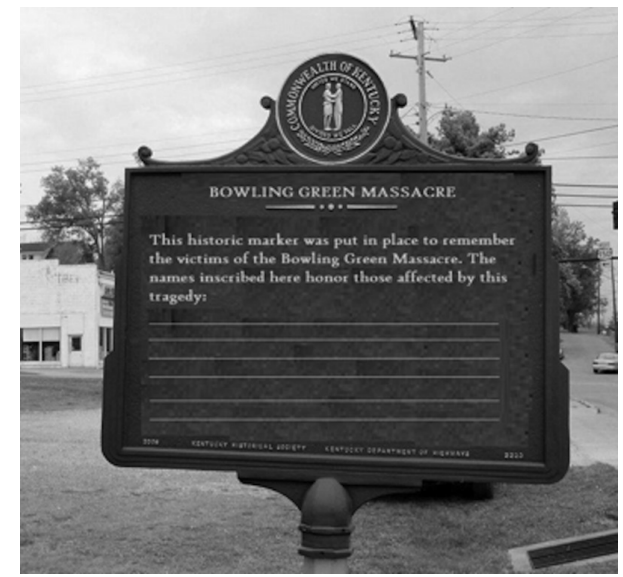




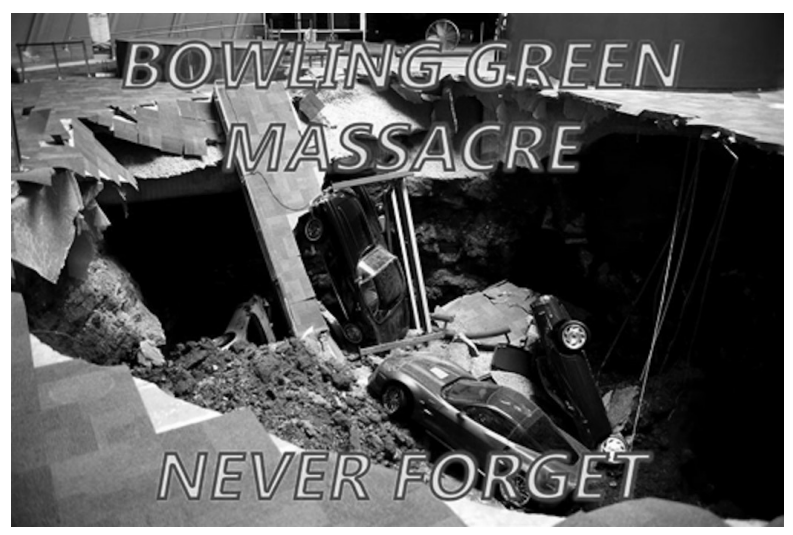

Figure 7. Bowling Green Massacre parody of the giant sinkhole that opened up and swallowed eight Corvettes at the National Corvette Museum in Bowling Green, February 12, 2014. Erika Brady Bowling Green Massacre Collection (personal communication, October 12, 2017).

Another popular local image or reference was to the sinkhole that had swallowed eight Corvettes at the National Corvette Museum in February 2014, noted by some political pundits and commentators as the issue that last put Bowling Green in the news.

Most of the Bowling Green residents I talked to noted the importance of understanding the local response in relation to Southern culture. ${ }^{8}$ Ann Ferrell said, "This is Kentucky, and we are used to being the butt of the joke. The vernacular responses were a way to take control and turn the joke around to those who normally joke about us. So there's also some sense of pride that someone else blundered, and we get to take it and make it a joke on them" (personal communication).

Timothy Evans notes that 'the massacre rapidly 'went viral', in a way that nothing else in Bowling Green has done in the eighteen years I've lived there, except possibly when the floor of the Corvette Museum collapsed into a sinkhole in 2014" (2018:461). Students at Western Kentucky University echoed these comments by posting on Facebook:

Fellow Hilltoppers: This is the moment for which all those hours sitting on that little half wall in front of Garrett prepared us. We were training to be the people our town ... no ... our country needed at its most desperate hour. When we few who survived the horrific massacre that never happened can go forth and tell our stories of how we bravely carried on in the face of uninterrupted everyday normalcy. We were training to be smartasses. We became heroes.

Another student posted, "This is the most exciting thing to happen to BGKY since the sinkhole ate half the Corvette Museum."

(quoted anonymously by Michael Ann Williams, personal communication, October 6, 2017)

Many of the memes, songs, jokes, tweets, and stories noted in this paper came from Erika Brady's gracious forwarding of materials from students in her Roots of Southern Culture class. By capturing the local in referencing Southern historic markers, Big Red, local football, and the Bowling Green sinkhole, the responses use connections to the local to ground vernacular critique in the experiential contexts out of which they 
emerge. Evans notes local places, such as City Hall, the fountain on Fountain Square in downtown Bowling Green, or the Bowling Green Corvette Museum in the responses (2018). He also notes that Bowling Green has an active refugee resettlement scene that makes local residents sensitive to the massacre's attempt to attack immigrants. These are local facts, contextual information put forward in part to demonstrate knowledge superior to that of the Trump administration. Perhaps more than anything else, localness is responsible for the fast critique. It is clear that Bowling Green knows best what is happening in its own midst and that the White House operates both at a distance and at a local disadvantage. The response pits the experience of being there on the ground against hegemonic power operating at a distance.

\section{Incongruity}

Almost all forms of humor contain some form of incongruity (Oring 1987), but in the case of responses to fake news, incongruity is built into both the nature of the joke and the administratively manipulated news itself.

One common quality of the Bowling Green Massacre responses is a parodied use of incongruity, with some memes, tweets, lyrics, and posts leaving everyone scratching their heads in confusion. This is purposeful, highlighting the constant and seemingly intentional incongruity of White House assertions, a communicative strategy the White House has repeatedly used since the inauguration.

It is unclear if the White House incongruities are always intentional, but they are readily apparent. For example, on November 27, 2017, during an event honoring Navajo Code Talkers who assisted US Marines during World War II in sending coded messages in the Pacific Theater, President Trump referenced his nickname for Senator Elizabeth Warren, whom he insisted on calling "Pocahontas." The use of that name was even more incongruous, as the entire event played out in front of a portrait of President Andrew Jackson, considered an enemy of Native peoples because he signed into law the 1830 Indian Removal Act.

The strange pairing of messages and symbols seems designed to defy logic, challenging our thinking by disrupting conventional norms. As Ann noted, it is a "continual

Figure 8. Frederick Douglass, Rosa Parks, Harriet Tubman, Beyoncé Knowles' twin children, the Bowling Green Massacre, and the Underground Railroad, parody image "courtesy of the Bowling Green Museum of Fictional History." Erika Brady Bowling Green Massacre Collection (personal communication, October 12, 2017).

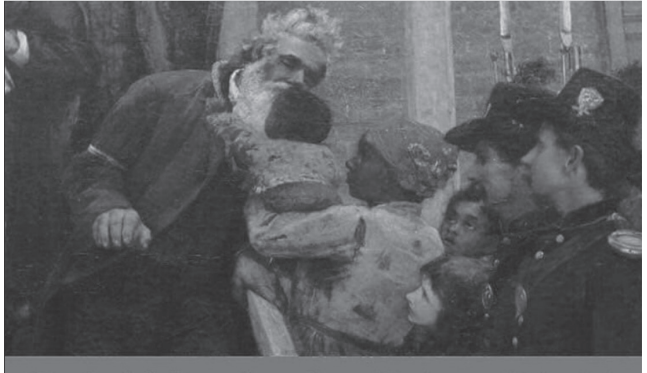

Frederick Douglass, Rosa Parks, and Harriet Tubman smuggling Beyonce Knowles' twin children out of Bowling Green Massacre on Underground Railroad.

Image Courtesy of Bowling Green Museum of Fictional History 
pointed effort to make us all feel that our head is spinning" (personal communication, October 6, 2017). Comedian John Oliver commented during the presidential campaign: "Trump's message is most consistent in its inconsistency—and his campaign is chock-full of incongruities" (quoted in Mallon 2016). A ballad written by Dave Stinton entitled "That Day in Bowling Green" draws further attention to the role incongruity plays in fake news strategies:

I gazed across those lollipop fields

to the unicorn machine

when I saw the lie my enemy wields

'Gainst our lovely Bowling Green.

(2017)

Above all else, the incongruity of vernacular response casts light on what Ann noted was a continual pointed effort to make us all feel like our heads were spinning. The response matches incongruity with incongruity, pointing out what is seen as a deliberate Trump administration discursive strategy.

\section{Conclusion}

Each of these vernacular techniques of critique suggests collective action and organized rebellions that unleash what James Scott calls "the weapons of the weak" and "the powerful forms of everyday resistance" (1985). They establish non-cooperation, sabotage, and non-compliance all oriented toward diminishing the impact of the oppressive power of propaganda and "post-factness." The Bowling Green Massacre was a triple turning point. On one hand, it used the strength of local knowledge to quickly identify and counter the fake news nature of Conway's assertions. Secondly, it used vernacular humor and parody to identify, display, and critique the Trump administration's tactics (see Turner 2018). And third, and perhaps most importantly, it used the ridiculousness of the moment to point backward to similar moments and forward to identify future paths to resistance, develop collective solidarity, and create an index to the discursive strategies that did, do, and will require suspicion and continuous vigilance.

In this admirable community response, where might a folklorist fit in assessing bad faith communication and challenging fake news? By focusing on the emic vernacular power to crowd-source fact and reality and provide sophisticated, locally engaged critiques, scholars can both document and simultaneously promote resistance.

\section{Notes}

1. See Disbrow (2017).

2. Prior to Conway's statement, the ACLU had been very involved in challenging the Muslim ban. Their activities just the week before the February 2 statement by Conway included the following:

[On] Friday, January 27, 2017, President Donald Trump signed an Executive Order that banned foreign nationals from seven predominantly Muslim countries from visiting the country for 90 days, suspended entry to the country of all Syrian refugees indefinitely, and prohibited any other refugees from coming into the country for 120 days. As the Muslim ban went into effect on Saturday [January 28, 2017], lawyers from the ACLU-WA and the NW Immigrant Rights Project rushed to SeaTac Airport to help immigrants on incoming flights who were being denied entry to the U.S. The ACLU 
and NWIRP obtained a court order staying the deportation of two incoming travelers at SeaTac. With support from elected officials and more [than] 1,000 protesters, they secured the release of two people in the custody of Customs and Border Protection (CBP). [On] Sunday, January 29, 2017, a federal judge in New York granted the American Civil Liberties Union's request for a nationwide temporary injunction blocking the deportation of all people stranded in U.S. airports under President Trump's new Muslim ban. Four other courts also weighed in, each one a defeat for President Trump. The ACLU was involved in four of the five cases. Thursday, February 2, 2017, [t] he ACLU-WA submitted a friend of the court brief supporting the lawsuit filed in federal court by Washington Attorney General Bob Ferguson on Jan. 30 seeking to have key provisions of the President's Executive Order on immigration declared unconstitutional. (ACLU Washington n.d.)

3. Conway said, "I bet - there was very little coverage-I bet it's brand new information to people that President Obama had a six-month ban on the Iraqi refugee program after two Iraqis came here to this country, were radicalized - and they were the masterminds behind the Bowling Green massacre. I mean, most people don't know that because it didn't get covered" (MSNBC 2017).

4. In addition to the attack on the media suggested by Conway's invention of the Bowling Green Massacre, it cannot be forgotten that she deliberately ties Iraqis, and indeed all Muslims, to terrorism. As Caroline Mala Corbin notes,

we regularly witness the tendency to leap to the conclusion that Muslims were responsible for terror attacks. Take the U.S. media's coverage of the recent massacre at a mosque in Quebec City, where the shooter killed six people and injured another nineteen. Early reports suggested that police were holding two men. And indeed they were-one born in Canada and one born in Morocco, a majority-Muslim country. Fox News tweeted out that there was a single Moroccan suspect: "Suspect in Quebec mosque terrorist attack was of Moroccan origin." In fact, the gunman was the white French Canadian; the Moroccan-born man, Mohamed Belkhadir, was the one who had called the police when he heard shots. (2017:459)

Corbin continues:

Indeed, once stereotypes take hold, they can be so strong that we may "remember" stereotype-consistent acts that did not even occur. This cognitive error may explain how White House Spokesperson Kellyanne Conway "remembered" the Bowling Green massacre by two Iraqi refugees, an incident that existed only in the imagination of Kellyanne Conway. (2017:465)

5. Discussing why former President Barack Obama halted refugees from Iraq in 2011, Conway explained to Cosmopolitan on January 29, 2017: "He did that because two Iraqi nationals came to this country, joined ISIS, traveled back to the Middle East to get trained and refine their terrorism skills and come back here, and were the masterminds behind the Bowling Green massacre of taking innocent soldiers' lives away" (quoted in Mascia 2017).

6. $T M Z$ is a syndicated entertainment and celebrity gossip news television show. See TMZ (2017) for Conway's words on January 29.

7. Empire BBK, February 3, 2017, https://www.empireboobookitty.com/2017/02/bowling-greenmassacre-memes/.

8. Thank you to Erika Brady, Ann Ferrell, and Michael Ann Williams, residents of Bowling Green who sent materials and responded to my questions.

\section{References Cited}

ACLU Washington. n.d. Timeline of the Muslim Ban. https://www.aclu-wa.org/pages/timeline-muslim -ban (accessed March 22, 2018).

Beauchamp, Zack. 2017. “Kellyanne Conway Made up a Fake Terrorist Attack to Justify Trump’s 'Muslim Ban.” Vox, February 2. https://www.vox.com/world/2017/2/2/14494478/bowling-green-massacre (accessed February 2, 2017).

Corbin, Caroline Mala. 2017. Terrorists Are Always Muslim but Never White: At the Intersection of Critical Race Theory and Propaganda. Fordham Law Review 86(4552):455-85. 
Coscarelli, Joe. 2017. Kellyanne Conway Admits “Bowling Green Massacre” Error. New York Times, February 3. https://www.nytimes.com/2017/02/03/us/politics/bowling-green-massacre -kellyanne-conway.html (accessed February 3, 2017).

Disbrow, Bill. 2017. Bowling Green Massacre Victims Fund [Website links to ACLU donation page]. San Francisco Chronicle, February 3. http://www.sfgate.com/news/article/Bowling-Green-Massacre -Victims-Fund-website-links-10906739.php (accessed February 3, 2017).

Evans, Timothy H. 2018. The Bowling Green Massacre. In "Fake News," ed. Tom Mould. Special issue, Journal of American Folklore 131(522):460-70.

Kalčik, Susan. 1975. “. . like Ann's gynecologist or the time I was almost raped”: Personal Narratives in Women's Rap Groups. Journal of American Folklore 88(347):3-11.

Mallon, Maggie. 2016. Watch John Oliver's Epic Takedown of Donald. Glamour, February 29. https:// www.glamour.com/story/john-oliver-donald-trump (accessed December 1, 2017).

Mascia, Kristen. 2017. That MSNBC Interview Was Not the First Time Kellyanne Conway Referred to the "Bowling Green Massacre." Cosmopolitan, February 6. https:/www.cosmopolitan.com/politics/ a8674035/kellyanne-conway-bowling-green-massacre-repeat/ (accessed March 7, 2018).

MSNBC. 2017. Kellyanne Conway Cites “Bowling Green Massacre” to Defend Refugee Ban | Hardball. YouTube video, February 2. 5:57 min. https://www.youtube.com/watch?v=g-w16cyQ8wQ (accessed February 28, 2018).

NBC News. 2017. Kellyanne Conway: Press Secretary Sean Spicer Gave "Alternative Facts"| Meet the Press. YouTube video, January 22. 1:06 min. https://www.youtube.com/watch?v=VSrEEDQgFc8 (accessed February 28, 2018).

Oring, Elliott. 1987. Jokes and the Discourse on Disaster. Journal of American Folklore 100(397):276-86.

Parthasarathy, Maya. 2017. 18 Bowling Green Massacre Memes \& Tweets Won’t Let Kellyanne Conway Live This One Down. Bustle, February 3. https://www.bustle.com/p/18-bowling-green-massacre -memes-tweets-wont-let-kellyanne-conway-live-this-one-down-35269.

Robertson, Lori, and Robert Farley. 2017. The Facts on Crowd Size. Fact Check, January 23. http://www .factcheck.org/2017/01/the-facts-on-crowd-size/ (accessed December 1, 2017).

Rubin, Jennifer. 2017. What President Trump's Sweden Moment Reveals. Washington Post, February 20. https://www.washingtonpost.com/blogs/right-turn/wp/2017/02/20/what-president-trumps-sweden -moment-reveals/?utm_term=.987143bab196 (accessed December 1, 2017).

Rutenberg, Jim. 2017. The Massacre That Wasn't: A “Fake News” Turning Point. New York Times, February 6:B1. https://www.nytimes.com/2017/02/05/business/the-massacre-that-wasnt-and-a-turning-point -for-fake-news.html.

Scott, James C. 1985. Weapons of the Weak: Everyday Forms of Peasant Resistance. New Haven, CT: Yale University Press.

Smith, David. 2017. Kellyanne Conway’s Fictitious "Bowling Green Massacre" Not a One-Time Slip of the Tongue. Guardian, February 6. https://www.theguardian.com/us-news/2017/feb/06/kellyanne -conway-fake-bowling-green-massacre-three-times (accessed February 6, 2017).

Smith, Oli. 2017. Sweden "Covering Up" Migrant Rape and Violent Crime for the Sake of "Humanitarianism." Express, February 20. https://www.express.co.uk/news/world/768980/Sweden-cover-up-migrant -rape-violent-crime (accessed March 7, 2018).

Stinton, Dave. 2017. That Day in Bowling Green. Bandcamp, February 5. https://nickandgabe.bandcamp .com/track/that-day-in-bowling-green (accessed December 1, 2017).

TMZ. 2017. Kellyanne Conway ... Obama Started the Muslim Ban. YouTube video, January 29. 1:06 min. https://www.youtube.com/watch?v=uNgvoTx1fRo\&feature=youtu.be (accessed March 7, 2018).

Turner, Patricia A. 2018. Respecting the Smears: Anti-Obama Folklore Anticipates Fake News. In "Fake News," ed. Tom Mould. Special issue, Journal of American Folklore 131(522):421-5.

Wootson, Cleve R., Jr. 2017. Trump Implied Frederick Douglass Was Alive. The Abolitionist's Family Offered a "History Lesson." Washington Post, February 2. https://www.washingtonpost.com/news/ post-nation/wp/2017/02/02/trump-implied-frederick-douglass-was-alive-the-abolitionists-family -offered-a-history-lesson/?utm_term=.8cf8c3bcbe4f (accessed March 28, 2018). 